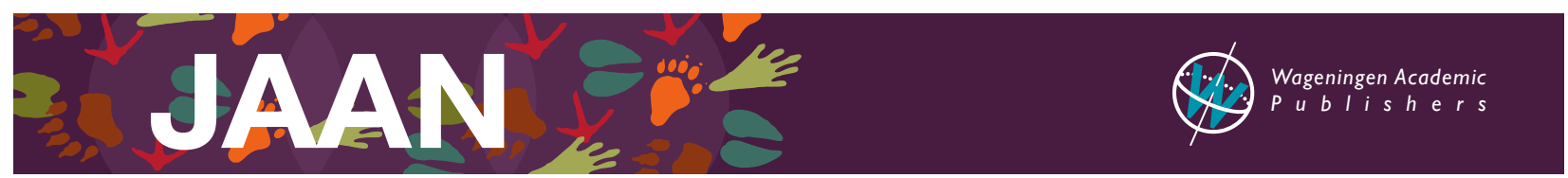

\title{
Effect of total replacement of inorganic with organic sources of key trace minerals on performance and health of high producing dairy cows
}

\author{
P.H. Pomport ${ }^{1}$, H.E. Warren ${ }^{2 *}$ and J. Taylor-Pickard ${ }^{2}$ \\ ${ }^{1}$ AgroParisTech-Ferme de Grignon, Route de la ferme, 78850 Thiverval-Grignon, France; ${ }^{2}$ Alltech European Bioscience \\ Centre, Sarney, Summerhill Road, Dunboyne, Co. Meath, Ireland; hwarren@alltech.com
}

Received: 23 September 2020 / Accepted: 19 January 2021

(c) 2021 P.H. Pomport et al.

\section{RESEARCH ARTICLE DAIRY COWS}

\begin{abstract}
The aim of this trial was to compare the effect of complete replacement of certain inorganic trace minerals with organic, chelated minerals (Bioplex ${ }^{\oplus}$, Selplex; ${ }^{\oplus}$ Alltech Inc, USA) against standard and reduced inorganic mineral levels in feed on the performance and health of dairy cows during a 10-week trial (W0-W10) period. Three treatment groups, each containing 36 dairy cows, were assigned to one of three diets that varied only in mineral feed composition: (1) Inorganic (CON) $\mathrm{Cu}(1,042 \mathrm{mg} / \mathrm{kg}), \mathrm{Se}(26 \mathrm{mg} / \mathrm{kg})$ and $\mathrm{Zn}(4,200 \mathrm{mg} / \mathrm{kg})$ as per normal industry inclusion levels; (2) Inorganic (INORG) Cu (-35\%: $680 \mathrm{mg} / \mathrm{kg})$, Se (-60\%; $10 \mathrm{mg} / \mathrm{kg})$ and $\mathrm{Zn}(-66 \% ; 1,360 \mathrm{mg} / \mathrm{kg})$ (based on the lower organic levels in diet 3); and (3) Organic (proteinates and selenium-enriched yeast) minerals (ORG) $\mathrm{Cu}$, Se and $\mathrm{Zn}$ as per INORG levels. The cows in the ORG group had the highest milk yield (32.6 kg; $P=0.0165)$ with the INORG group the least $(31.3 \mathrm{~kg}$ ), production (energy corrected milk $31.5 \mathrm{~kg}(P=0.008)$ vs CON $31.0 \mathrm{~kg}$ and INORG 30.7 $\mathrm{kg})$, protein synthesis (ORG 1,024 g/d $(P<0.0001)$ vs CON 1,013 g/d and INORG $982 \mathrm{~g} / \mathrm{d})$ and ORG had the highest $(P<0.01)$ milk lactose content. There were no differences between treatments in plasma $\mathrm{Zn}, \mathrm{Cu}$ and GSH-PXE levels. Pregnancy rate and number of artificial insemination services appeared improved. Mastitis rates were lowest for the ORG group (two cows affected), vs four cows for the INORG group and six cows for the CON group. Somatic cell counts were consistently lower in the ORG cows $(P<0.05)$, being less than 300,000 cell counts, compared to peaks of 380,000 counts in the INORG and 550,000 counts in the CON groups. Five cows were affected by lameness in the INORG group, compared to three for the CON and one in the ORG groups.
\end{abstract}

Keywords: dairy cows, performance, health, organic minerals

\section{Introduction}

Minerals are essential to the health, welfare and productivity of dairy cows, as for all living things. Traditionally, inorganic forms of minerals have been most commonly applied in animal feeds and supplements. However, in the last 30 years, there has been the development of chelated minerals, bound to ligands, such as small peptides, which are often referred to as 'organic minerals'. These organic minerals are in the form akin to those found in natural plant and animal tissues. These are known to be taken up selectively from the gut (Webb et al., 2005).
The bioavailability of inorganic and organic forms of minerals has been compared in several species, where researchers have reported higher bioavailability for the latter El Ashry et al., 2012; Leeson, 2003; Nollet et al., 2007; Zhao et al., 2010) and have shown that lower levels of organic minerals can be used in total replacement of inorganic forms, without loss in animal performance (Perić et al., 2010). Numerous studies in non-ruminant species (Burkett, et al., 2009; Lin et al., 2017; Nollet et al., 2007; Qiu et al., 2020) have shown reduced mineral excretion following the use of organic trace mineral sources, but data on ruminants are more limited. Using lower levels 
of organic trace minerals allows faecal mineral output to be reduced whilst maintaining lactational performance, which is important for the environment. Pino and Heinrichs (2016) demonstrated reduced faecal Cu output when cows were fed $\mathrm{Cu}$ as a proteinate compared with a sulphate form across various dietary starch levels. Nocek et al. (2006) carried out a large-scale trial with dairy cows fed either $100 \%$ CON levels of inorganic or organic trace minerals (Zn-Met, Mn-Met, Cu-Lys, Co glucoheptonate) or 75\% CON levels of inorganic or organic minerals. The cows fed $75 \%$ CON levels of organic trace minerals achieved similar productive performance, reproductive and health status as cows fed $100 \%$ CON inorganic trace minerals. Such trials have demonstrated the capacity to reduce the amount of trace mineral supplementation in dairy diets when feeding organic trace minerals.

Many studies have reported benefits even from partial replacement of inorganic trace minerals with more bioavailable organic forms. Spears (1996) reported that zinc proteinate supplementation in dairy cows, replacing $50 \%$ of the total zinc content in feed, reduced mammary infections. Uchida et al. (2001) showed no difference in milk production but improved reproductive traits when they partially substituted the inorganic trace minerals with amino acid chelates $(\mathrm{Zn}, \mathrm{Mn}$ and $\mathrm{Cu})$ in the diets of early lactation dairy cows. Cows exhibited improved conception rates and fewer days to attain pregnancy $(P=0.012)$ and first service $(P=0.071)$, as well as lower number of services per conception $(P=0.069)$ compared with the control ration.

Studies comparing the performance of organic minerals as total replacement for inorganic minerals have supported the ability of organic minerals to improve performance and health or maintain performance when supplemented at lower levels. Horchanok et al. (2019) substituted organic forms ( $\mathrm{Mn}, \mathrm{Cu}$ and $\mathrm{Zn}$ ) for inorganic trace minerals (control) in dairy cow diets. They observed significant improvements milk yield $(21.3 \%$; $P<0.001)$ and increased protein and fat content of milk from cows fed organic minerals. Reproductive advantages were observed in the cows fed organic minerals, with 44 days shorter service interval and a lower insemination index than the control group. Ashmead and Samford (2004) found that feeding amino acid chelated trace minerals for 180 days over three consecutive lactation periods significantly increased production compared to those fed a similar diet containing inorganic trace minerals. This study demonstrated that the production benefits increased over consecutive lactation periods and, by the third lactation, body condition score of cows had improved in the group fed organic minerals. Feeding a combination of minerals as amino acid chelates increased conception rates, with fewer returns to service in first-calving, beef heifers (Kropp, 1990) compared to the group fed the inorganic mineral control diet.
Even replacement of single minerals with organic forms can be beneficial in dairy cow performance. A study by Cope et al. (2009) showed a significant benefit in milk yield from supplementing organic $\mathrm{Zn}$ to replace inorganic $\mathrm{Zn}(\mathrm{ZnO})$. The increased yield was $2.4 \mathrm{~kg} / \mathrm{d}$ over the 14 week period, with the majority of this gain being observed after the eighth week of supplementation, compared with the inorganic diet. In contrast to previous studies, Cope and colleagues observed that milk yield was not increased when the Zn content was lowered in the diet to below the NRC recommendations (both for organic and inorganic mineral forms).

Milk production is affected by bacterial contamination and somatic cell counts (SCC; Cinar et al., 2015), and SCC are commonly used as indicators of disease, which, when reduced, milk yield and quality improve. Cinar et al. (2015) discussed the negative impact of high SCC on milk yield in dairy cows. Kinal et al. (2005) studied the effect of incremental dietary replacement of inorganic trace elements with organic trace elements $(\mathrm{Zn}, \mathrm{Cu}$ and $\mathrm{Mn}$ ) on milk yield, quality and composition of milk in dairy cows fed three treatments pre- and post-parturition. The control (group 1 ) received $\mathrm{Zn}, \mathrm{Cu}$ and $\mathrm{Mn}$ in the inorganic sulphate form. The two treatment groups received $20 \%$ or $30 \%$ minerals supplied in the organic form (groups 2 and 3 , respectively). Group 2 ( $20 \%$ organic trace minerals) had the lowest SCC and total bacterial count, along with the best milk yield in the second and third month of lactation compared with group 1 (control) and group 3 (30\% organic trace minerals). There was a tendency for milk protein to increase in cows fed organic minerals. Cortinhas et al. (2010) found that feeding a mixture of $\mathrm{Zn}, \mathrm{Cu}$ and $\mathrm{Se}$ organic carboaminochelates tended to lower the average SCC $(P=0.056)$, subclinical mastitis cases $(P=0.014)$ and significantly lowered the number of cows with $>200,000$ cells $/ \mathrm{ml}$ as SCC $(P=0.001)$ in the first 80 days of lactation compared to feeding the same amount of inorganic trace mineral in sulphate form. In contrast, Cope et al. (2009) found that feeding both inorganic and organic $\mathrm{Zn}$ at NRC levels reduced somatic cell count, compared with lower Zn supplementation.

The aim of the current trial was to compare the lactation and reproductive performance, as well as incidence of mastitis and lameness in dairy cows fed either a full standard industry inclusion level inorganic mineral diet, a reduced inorganic mineral diet, or one where the same reduction was supplied using organic minerals.

\section{Materials and methods}

The trial was conducted on an experimental farm in France from April to June 2017. All experimental procedures were conducted according to the AgroParisTech Ethical Codes of 
Practice, Paris, France. A total of 108 Holstein dairy cows (parity 2.2 \pm 1.3 ; aged $3.8 \pm 1.5$ years; bodyweight $641 \pm 6 \mathrm{~kg}$ ) were used for the study and split into three groups of 36 animals, housed in indoor cubicles. The diets the cows were given is shown in Table 1 and the nutrient profile of the diet is shown in Table 2.

The cows were allocated to one of three homogeneous groups based on an array of production parameters (Table 3.). All groups were fed the same basal diet with the only difference being the composition of the mineral feed: CON - inorganic $\mathrm{Cu}(1,042 \mathrm{mg} / \mathrm{kg})$, Se (26 mg/kg) and Zn (4,200 $\mathrm{mg} / \mathrm{kg}$ ) given based on standard French industry levels; INORG - inorganic Cu (680 mg/kg), Se (10 mg/kg) and Zn $1,360 \mathrm{mg} / \mathrm{kg}$ ) given based on the lower ORG levels; ORG $\mathrm{Cu}$, and $\mathrm{Zn}$ given as Bioplex ${ }^{\odot}$ and Se as Sel-Plex ${ }^{\circledR}$ (Alltech Inc., Lexington, KY, USA), based on the manufacturer's recommended levels. The composition of the minerals given to the three experimental groups for a 10-week period (W0-W10) is shown in Table 4.

Feed rations were given once per day and any feed refusals were measured daily to determine group dry matter intake (DMI) and feed efficiency. Monthly individual body weights, body condition scores (BCS), lameness and locomotion scores were measured. Locomotion scoring (LS) was based on the observation of the cows standing and walking, with emphasis on their back posture. Lameness and locomotory evaluations were done after milking on a flat surface for each cow by the same evaluator throughout the trial. The overall LS was based on the highest score recorded for each cow over the three indicators: back posture standing (score 1 - flat back, score 2 - arched back), back posture walking (score 1 - flat back, score 2 - arched back) and stride (length and evenness).

Table 1. Diets of the three experimental groups of dairy cows. ${ }^{1}$

$\begin{array}{llll}\text { Ingredient }^{2} & \text { CON } & \text { INORG } & \text { ORG } \\ \text { Corn silage (DM) } & 6.42 & 6.47 & 6.40 \\ \text { Sugar beet pulp (DM) } & 1.22 & 1.23 & 1.29 \\ \text { Alfalfa silage (DM) } & 2.93 & 2.95 & 2.98 \\ \text { Alfalfa hay } & 1.23 & 1.24 & 1.24 \\ \text { Rapeseed chaff } & 1.86 & 1.88 & 1.89 \\ \text { Rapeseed cake expeller } & 1.27 & 1.28 & 1.29 \\ \text { Rapeseed cake 35 } & 2.14 & 2.16 & 2.17 \\ \text { Barley } & 2.12 & 2.13 & 2.15 \\ \text { Crushed corn grain } & 3.29 & 3.31 & 3.40 \\ \text { Minerals } & 0.30 & 0.30 & 0.30 \\ \text { Sodium bicarbonate } & 0.12 & 0.12 & 0.12 \\ \text { Salt } & 0.05 & 0.05 & 0.05 \\ \text { Calcium carbonate } & 0.04 & 0.04 & 0.04 \\ \text { DMI (kg DMI/cow/day) } & 23.0 & 23.2 & 23.3\end{array}$

${ }^{1} \mathrm{CON}=100 \%$ inorganic; INORG = reduced inorganic; $\mathrm{ORG}=$ reduced organic.

${ }^{2} \mathrm{DM}=$ dry matter; $\mathrm{DMl}=$ dry matter intake.

${ }^{3}$ Different minerals were administered to the different experimental groups.

Individual milk production was collected daily from cows in a $2 \times 12$ herringbone parlour and individual milk composition and quality was measured fortnightly over four consecutive collections. Milk samples were characterised by mid-infrared interferometry (Fourier transformation). Absorbances at wavelengths corresponding to the functional groupings characteristic of the components to be assayed were extracted from these spectra by digital processing, using $\mathrm{CH}$ groups at around $3.5 \mu \mathrm{m}$ (filter B) for the determination of the fat content, secondary amide groups of peptide bonds at around $6.5 \mu \mathrm{m}$ for determining protein content and the hydroxyl group of lactose at around $9.6 \mu \mathrm{m}$ for the determination of lactose.

Milk was corrected for energy, and fat and protein transfer were calculated. Energy corrected milk (ECM) takes into account the energetic cost for the synthesis of fat, protein and lactose, to convert milk yield into a standardised milk with $38 \mathrm{~g} / \mathrm{l}$ fat, $32 \mathrm{~g} / \mathrm{l}$ protein and $50 \mathrm{~g} / \mathrm{l}$ lactose, calculated using the formula in Box 1 (INRA, 2007).

\section{Table 2. Nutrient profile of the basal diet.}

$\begin{array}{ll}\text { Nutrient }^{1} & \text { Value } \\ \text { Dry matter (\%) } & 51.8 \\ \text { Crude protein (\%) } & 16.2 \\ \text { UFL } & 0.92 \\ \text { PDIA }(\mathrm{g} / \mathrm{kg}) & 47.0 \\ \text { PDIN }(\mathrm{g} / \mathrm{kg}) & 104.0 \\ \text { PDIE }(\mathrm{g} / \mathrm{kg}) & 98.0 \\ \text { Fat }(\%) & 2.6 \\ \text { Starch }(\%) & 23.0 \\ \text { Cellulose }(\%) & 17.7 \\ \text { NDF }(\%) & 35.6 \\ \text { ADF }(\%) & 21.4\end{array}$

${ }^{1} \mathrm{ADF}=$ acid detergent fibre; NDF = neutral detergent fibre; PDIA = digestible protein from feed; $\mathrm{PDIE}=$ total protein when $\mathrm{E}$ limiting; $\mathrm{PDIN}=$ total protein when $\mathrm{N}$ limiting; UFL = net energy for milk production. 
Table 3. Main characteristics of experimental groups before being physically separated into treatment groups. ${ }^{1,2}$

$\begin{array}{llll}\text { Parameter } & \text { CON } & \text { INORG } & \text { ORG } \\ \text { Milk yield }(\mathrm{kg} / \mathrm{d}) & 35.4( \pm 6.8) & 35.4( \pm 7.4) & 35.4( \pm 7.9) \\ \text { Days in milk (d) } & 148( \pm 70) & 152( \pm 71) & 148( \pm 66) \\ \text { Energy-corrected milk (kg/d) } & 34.4( \pm 6.2) & 34.4( \pm 6.4) & 34.5( \pm 6.5) \\ \text { Fat synthesis }(\mathrm{g} / \mathrm{d}) & 1,267( \pm 252) & 1,269( \pm 252) & 1,274( \pm 245) \\ \text { Protein synthesis }(\mathrm{g} / \mathrm{d}) & 1,100( \pm 191) & 1,100( \pm 201) & 1,101( \pm 210) \\ \text { Lactose }(\mathrm{g} / \mathrm{l}) & 52.8( \pm 1.6) & 52.7( \pm 1.5) & 52.8( \pm 1.6) \\ \text { Urea }(\mathrm{g} / \mathrm{l}) & 256( \pm 25) & 250( \pm 33) & 251( \pm 33) \\ \text { Fat content }(\mathrm{g} / \mathrm{l}) & 37.1( \pm 4.2) & 37.5( \pm 5.1) & 37.6( \pm 4.7) \\ \text { Protein content }(\mathrm{g} / \mathrm{l}) & 32.3( \pm 2.3) & 32.4( \pm 2.6) & 32.4( \pm 2.7) \\ \text { Body weight }(\mathrm{kg}) & 639( \pm 65) & 639( \pm 67) & 645( \pm 76)\end{array}$

${ }^{1} \mathrm{CON}=100 \%$ inorganic; INORG = reduced inorganic; $\mathrm{ORG}=$ reduced organic.

2 Values are mean \pm standard deviation.

Table 4. Composition of mineral feeds for the three experimental groups of dairy cows (fresh weight basis). ${ }^{1,2}$

$\begin{array}{llll}\text { Mineral } & \text { CON } & \text { INORG } & \text { ORG } \\ \text { Vitamin A (IU/kg) } & 500 & 500 & 500 \\ \text { Vitamin } D_{3}(I \mathrm{IUg}) & 67 & 67 & 67 \\ \text { Vitamin E (IU/kg) } & 2,000 & 2,000 & 2,000 \\ \mathrm{Ca}(\%) & 24 & 24 & 24 \\ \mathrm{P}(\%) & 0 & 0 & 0 \\ \mathrm{Na}(\%) & 2.8 & 2.8 & 7 \\ \mathrm{Mg}(\%) & 7 & 7 & 120 \\ \mathrm{I}(\mathrm{mg} / \mathrm{kg}) & 120 & 120 & 680 \\ \mathrm{Mn}(\mathrm{mg} / \mathrm{kg}) & 1,100 & 680 & 680^{* *} \\ \mathrm{Cu}(\mathrm{mg} / \mathrm{kg}) & 1,042^{*} & 1,360^{*} & 1,360^{* *} \\ \mathrm{Zn}(\mathrm{mg} / \mathrm{kg}) & 4,200^{*} & 10^{*} & 10^{* *} \\ \mathrm{Se}(\mathrm{mg} / \mathrm{kg}) & 26^{*} & 40 & 40 \\ \mathrm{Co}(\mathrm{mg} / \mathrm{kg}) & 40 & & \end{array}$

Box 1. Formula for calculating energy corrected milk (ECM) (INRA, 2007).

$$
\operatorname{ECM}(\mathrm{kg})=\frac{\text { crude milk yield }(\mathrm{kg}) \times(\mathrm{fat}(\mathrm{g} / \mathrm{l}) \times 9.6+\text { protein }(\mathrm{g} / \mathrm{l}) \times 5.6+\text { lactose }(\mathrm{g} / \mathrm{l}) \times 4.2}{(38 \times 9.6+32 \times 5.6+50 \times 4.2) \times 1.033}
$$

Pooled milk samples by group were analysed three times during the trial (at W0, W5 and W10) to count and identify cell differentiation. Inflammatory responses within the mammary gland were determined from the populations of lymphocytes, mast cells and polymorphonuclear neutrophils (PMN). At W0, W5 and W10, two blood samples from all cows were collected for individual analysis. Blood samples were taken from the jugular vein using Vacutainer tubes containing lithium heparin as an anticlotting agent. One sample per cow was used for whole blood glutathione peroxidase (GSH-PXE) analysis by the colorimetry method (Hawkes and Craig, 1990), as this enzyme is related to Se availability and animal antioxidant status. The second samples were centrifuged for $10 \mathrm{~min}$ at 2,000 $\times g$ to separate plasma and were used to analyse $\mathrm{Zn}, \mathrm{Cu}$ and GSH-PXE. $\mathrm{Zn}$ and $\mathrm{Cu}$ were assayed at the ENVT laboratory in Toulouse by atomic absorption spectrometry. Plasma GSH-PXE was analysed at Iodolab (Marcy-l'Étoile, France) by colorimetry according to the Paglia and Valentine (1967) method with a RANSEL kit (RANDOX). The assays were carried out automatically on a BM6010 analyser (JEOL, Tokyo, Japan).

Milk production and milk quality results were averaged per week and analysed using repeated data analysis with a mixed linear model in $\mathrm{SAS}^{\ominus}$ version 9.1.3 (SAS Institute Inc., Cary, NC, USA). Body weights and BCS were analysed using ANCOVA GLM in SAS. No covariates were included in the statistical analysis, rather the data were tested (Bartlett's test) to ensure homogeneity, which was determined between groups at W0 only. No statistics were run on the DMI, feed efficiency and other related variables, as these were only available as group data. Statistical analyses were carried out for the whole test period (W0 to W10) and W4 to W10. No statistics could be applied for artificial insemination (AI), reproduction or inflammatory cell data, as only three results per group per variable were available. 


\section{Results and discussion}

Some cows had to be removed from the trial for each of the three groups. Two cows were removed from the $\mathrm{CON}$ group due to leg issues (abscesses), one at W5 and the other at W9; two cows were removed from the INORG group, one due to leg issues (W8) and one due to pericarditis (W9); two cows had to be removed from the ORG group, one due to a lack of milk and one due to a housing issue (both at W6). There were no differences over the trial period in body condition score or weight.

Feeding, milk production and quality results are shown in Table 5. No difference in DMI, body weight or BCS was found between the treatment groups.

The ORG group had significantly $(P<0.0165)$ higher milk yield, at $32.6 \mathrm{~kg} / \mathrm{d}$, compared to the other two treatment groups. The INORG group had the lowest milk production, at $31.3 \mathrm{~kg} / \mathrm{d}$. These differences were evident from W3 until W10. Correcting milk for energy resulted in the ORG group having the highest milk yield $(P<0.05$; Table 4$)$. This result was in agreement with the findings of Ashmead and Samford (2004), who reported significant increases in milk yield from cows fed organic forms of minerals. Even when only $20 \%$ of the minerals were replaced with organic forms, milk yield was the highest compared to the inorganic control group (Kinal et al., 2005). More recently, Horchanok et al. (2019) reported that feeding organic forms of minerals increased milk yield, as well as milk quality (fat, protein and lactose). The findings of the current trial exceeded those reported by Harrison et al. (2006), Nocek et al. (2006) and Petrovic et al. (2010), who reported no changes in milk yield from dairy cows fed reduced levels of organic minerals in comparison with full levels of inorganic forms. The additional benefits from ORG, even at lower levels of inclusion, was considered to be due to its increased mineral bioavailability El Ashry et al., 2012).
The ECM was the lowest in the INORG group $(30.7 \mathrm{~kg} / \mathrm{d})$ compared to the ORG and CON groups $(31.5$ and $31.0 \mathrm{~kg} / \mathrm{d}$, respectively), and the ORG group had significantly higher ECM $(P=0.008)$ compared to the INORG group. There was an increase in ECM for the ORG group from W2 and W3, which was related to the increase in milk production during this period. Similarly, the decrease in ECM for the INORG group from W7 to W10 may have been related to a decrease in milk production at this time. Feed efficiency remained stable, ranging between 1.24 and $1.51 \mathrm{~kg}$ of ECM per $\mathrm{kg}$ of dry matter during the trial.

There were no significant differences in fat synthesis between treatment groups over the whole trial period, although this was numerically highest for the ORG group $(1,232 \mathrm{~g} /$ day $)$ followed by the CON group (1,226 g/day) and the INORG group $(1,207 \mathrm{~g} /$ day $)$. Fat content of the milk increased during the initial part of the trial, reaching a maximum in the middle of the trial period and then decreasing after W8. The ORG group was lower overall than the other two groups during the second part of the trial (after W3), with a fat content of $39.4 \mathrm{~g} / \mathrm{l}$ compared to $39.8 \mathrm{~g} / \mathrm{l}$ for the CON group and $40.2 \mathrm{~g} / \mathrm{l}$ for the INORG group $(P=0.03)$.

Protein synthesis was significantly different between groups, with the highest $(P<0.0001)$ seen in the ORG group $(1,024$ g/day) compared to the CON (1,013 g/day) and INORG (982 g/day) groups. As with fat content, protein in milk increased during the first part of the study for all three groups. From W5 onwards, three trends $(P<0.1)$ appeared; protein content decreased from W4 to W7 in all groups, and then increased sharply in W8, with the CON group milk being the highest compared to the other two groups. This trend was particularly prominent in the second part of the trial, however, this was not significant (data not shown). The ORG group had the highest $(P<0.01)$ lactose content compared to the other two groups during the whole trial.

Table 5. Effect of feeding industry (CON) levels of inorganic minerals versus lower levels of inorganic (INORG) or organic (ORG) minerals for 10 weeks on feeding, lactation and milk quality in dairy cows. ${ }^{1}$

\begin{tabular}{|c|c|c|c|c|c|}
\hline Parameter ${ }^{2}$ & $\begin{array}{l}\text { CON } \\
\text { (100\% inorganic) }\end{array}$ & $\begin{array}{l}\text { INORG } \\
\text { (reduced inorganic) }\end{array}$ & $\begin{array}{l}\text { ORG } \\
\text { (reduced organic) }\end{array}$ & SD & $P$-value \\
\hline Feed intake $(\mathrm{kg} / \mathrm{d} \mathrm{DM})^{3}$ & 23.0 & 23.2 & 23.3 & - & - \\
\hline Milk yield $(\mathrm{kg} / \mathrm{d})$ & $32.0^{a}$ & $31.3^{a}$ & $32.6^{b}$ & 2.39 & 0.0165 \\
\hline Energy corrected milk (kg/d) & $31.0^{\mathrm{a}}$ & $30.7^{a}$ & $31.5^{\mathrm{b}}$ & 2.59 & 0.005 \\
\hline Feed efficiency (kg ECM/kg feed) ${ }^{3}$ & 1.39 & 1.35 & 1.39 & - & - \\
\hline Fat synthesis $(\mathrm{g} / \mathrm{d})$ & 1,226 & 1,207 & 1,232 & 133 & 0.3900 \\
\hline Milk fat content ( $\mathrm{g} / \mathrm{l})$ & 39.8 & 40.2 & 39.4 & 3.82 & 0.1300 \\
\hline Protein synthesis (g/d) & $1,013^{a}$ & $982^{\mathrm{a}}$ & $1,024^{b}$ & 86 & 0.05 \\
\hline Protein content $(\mathrm{g} / \mathrm{l})$ & 32.9 & 32.6 & 32.6 & 1.47 & 0.3300 \\
\hline Lactose $(g / l)$ & $50.8^{a}$ & $50.8^{a}$ & $51.2^{b}$ & 1.18 & 0.0001 \\
\hline
\end{tabular}

${ }^{1}$ Means with different superscripts are significantly different $(P>0.05)$

2 DM = dry matter; ECM = energy corrected milk.

3 Group data, so not statistically analysed. 
These findings, in terms of increases in fat, protein and lactose increases in milk from cows fed the ORG diets, were in agreement with other studies. For example, although fat was not altered in the current trial, Horchanok et al. (2019) reported increases in fat and protein transfer into milk when cows were given feed where organic minerals replaced inorganic forms.

The ORG group tended $(P=0.05)$ to have lower somatic cell counts (SCC) overall compared to the other two groups (Figure 1). Analysis of individual cow data showed that, within the CON group, three animals had high SCC throughout the experiment with two cows in this group having high SCC from the start of the trial. The higher SCC within this group can be largely attributed to these five animals. This was in agreement with the published findings of Kinal et al. (2005), Cope et al. (2009) and Cortinhas et al. (2010), who reported that the lowest SCC were seen in cows fed diets either with total or partial replacement of inorganic minerals with organic sources or single mineral replacement compared to inorganic control diets.

Results for blood plasma copper, zinc and glutathione peroxidase are shown in Table 6. Both $\mathrm{Cu}$ and $\mathrm{Zn}$ values fell within normal reference ranges (Spolders et al., 2010). No clear trend was seen in the blood parameters $(\mathrm{Zn}, \mathrm{Cu}$ and GSH-PXE) measured, although all three groups showed an increase in GSH-PXE concentration during the trial. Zinc levels were higher in the CON and INORG groups compared to the ORG group between W0 and W10 and GSH-PXE was higher in the CON (+45 U/g Hb) and ORG (+39 U/g Hb) groups compared to the INORG (+21 U/g $\mathrm{Hb})$ group between W5 and W10.

Although unable to evaluate the data by more robust statistical methods, there were no differences in the proportion of pregnant cows between treatments (Table 7). Twenty-four cows were pregnant in the ORG group

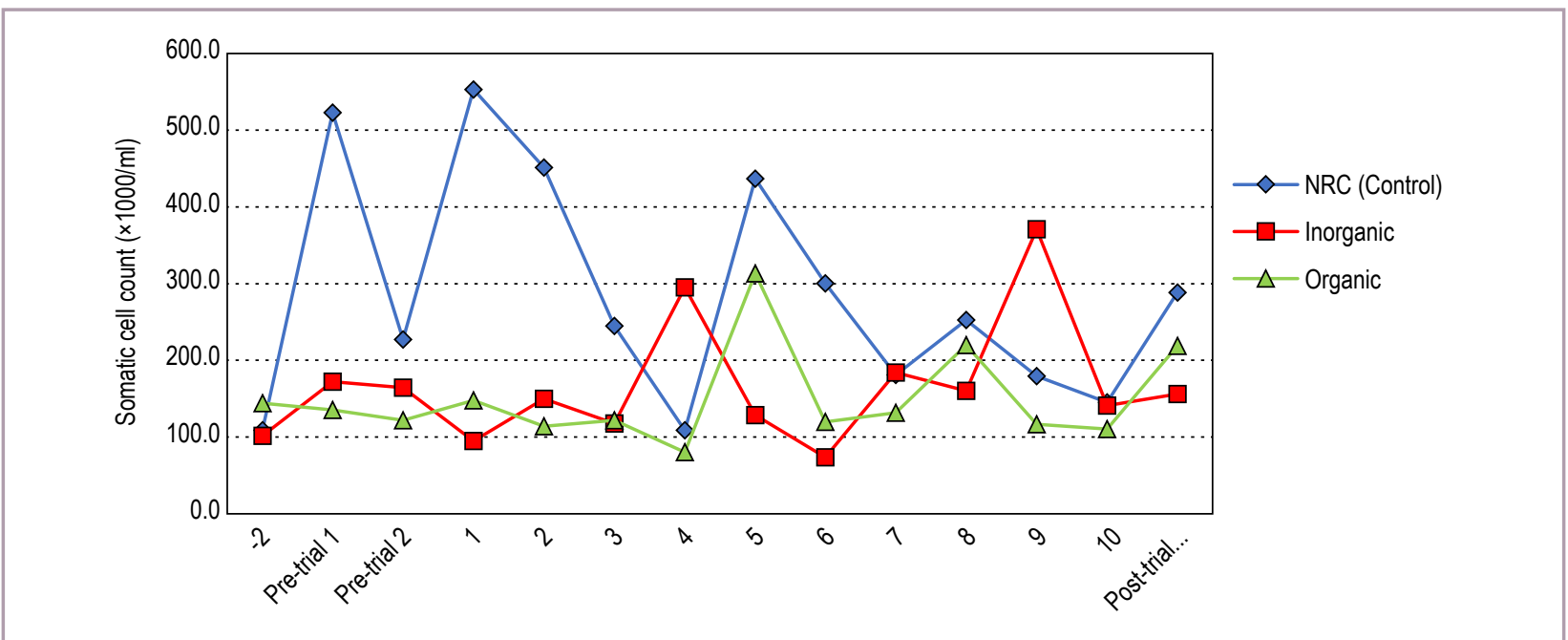

Figure 1. Somatic cell content over time from dairy cows fed three diets differing in level of source of minerals.

Table 6. Effect of feeding industry (CON) levels of inorganic minerals versus lower levels of inorganic (INORG) or organic (ORG) minerals on plasma $\mathrm{Cu}$ and $\mathrm{Zn}(\mu \mathrm{mol} / \mathrm{l})$ and glutathione peroxidase (GSH U/g Hb) at weeks 0,5 and 10 of the trial.

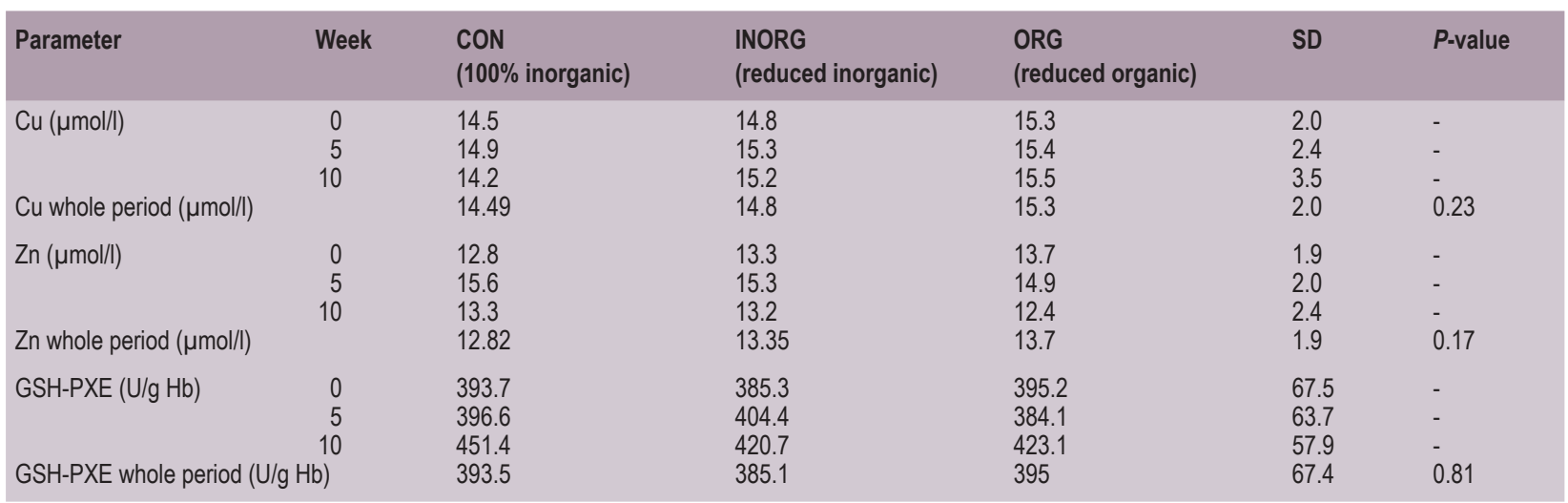


Table 7. Effect of feeding industry (CON) levels of inorganic minerals versus lower levels of inorganic (INORG) or organic (ORG) minerals on reproductive performance in dairy cows.

\begin{tabular}{llll} 
Parameter & CON (100\% inorganic) & INORG (reduced inorganic) & ORG (reduced organic) \\
\hline Artificial insemination services $(n)$ & 21 & 26 & 16 \\
Pregnancies from services & $1 / 21$ & $3 / 26$ & $6 / 16$ \\
Pregnancy $(\%)$ week 4 1 & 44 & 44 & 53 \\
Pregnancy $(\%)$ week $10^{2}$ & 47 & 53 & 71 \\
Pregnancy increase (\%) & 3 & 9 & 18 \\
${ }^{1} P=0.700$ (chi square). & & & \\
${ }^{2} P=0.1300$ (chi square). & & &
\end{tabular}

whereas there were only 18 pregnant cows in the INORG group and 16 in the CON group after W10. Thus, the cows in the ORG group had the lowest number of AI services.

These findings were in contrast with the data published by Kropp et al. (1990), Uchida et al. (2001), Nocek et al. (2006) and Horchanok et al. (2019), who reported improvements in reproductive performance in dairy cows fed organic forms of minerals, compared to inorganic control diets. These published benefits included reduced empty days, fewer AI services and higher pregnancy rates.

The number of mast cells, lymphocytes and PMN were recorded from pooled, group milk samples at W0, W5 and W10 of the trial. The proportion of mast cells, lymphocytes and PMN in milk was similar for all three groups. However, the proportions of PMN in the CON (48\%) and ORG (48\%) groups increased numerically more during the study compared to the INORG group (44\%). Interpretation of these data is limited due to the nature of trial design. The ORG group had the lowest case of mastitis with cases seen in only two cows, whereas the CON group registered 10 mastitis cases for six cows and the INORG group was intermediate with four cases. Reduced mastitis cases have previously been reported in dairy cows fed diets formulated with organic minerals by Cortinhas et al. (2009).

The INORG and CON groups suffered more leg and hoof issues compared to the ORG group. There were five lameness cases in the INORG group, three in the CON and only one in the ORG groups. The trial demonstrated that the use of LS was effective for early detection of hoof issues and comparing the incidence and severity of lameness in cows. Again, interpretation was limited, however, this was in agreement with previous trials (Nocek et al., 2006), which reported increases in health status in dairy cows fed organic minerals, which was likely to be related to the reduced lameness shown in the current trial.

\section{Conclusions}

The cows in the ORG group had improved milk production, quality and ECM. There was a lack of statistical effect on reproduction parameters, although this finding was limited by trial design. To conclude, feeding organic forms of minerals to dairy cows, even at lower levels compared to standard French feed industry levels, improved production performance.

\section{Acknowledgments}

The authors would like to thank Alltech Inc, USA for funding this project.

\section{Declaration of interest}

H.E. Warren and J. Taylor-Pickard are employees of Alltech Inc, USA.

\section{References}

Ashmead, H.D. and Samford, R.A., 2004. Effects of metal amino acid chelates or inorganic minerals on three successive lactations in dairy cows. International Journal of Applied Research in Veterinary Medicine 3: 181-188.

Burkett, J.L., Stalder, K.J., Powers, W.J., Bregendahl, K., Pierce, J.L., Baas, T.J., Bailey, T. and Shafer, B.L. 2009. Effect of inorganic and organic trace mineral supplementation on the performance, carcass characteristics, and fecal mineral excretion of phase-fed, growfinish swine. Asian-Australasian Journal of Animal Sciences 22(9): 1279-1287.

Cinar, M., Serbester, U., Ceyhan, A. and Gorgulu, M. 2015. Effect of somatic cell count on milk yield and composition of first and second lactation dairy cows. Italian Journal of Animal Science 14(1): 3646.

Cope, C.M., Mackenzie, A.M., Wilde, D. and Sinclair, L.A., 2009. Effects of level and form of dietary zinc on dairy cow performance and health. Journal of Dairy Science 92(5): 2128-2135.

Cortinhas, C.S., Botaro, B.G., Sucupira, M.C.A., Rennó, F.P. and Santos, M.V.D., 2010. Antioxidant enzymes and somatic cell count in dairy cows fed with organic source of zinc, copper and selenium. Livestock Science 127(1): 84-87. 
El Ashry, G.M., Hassan, A.A.M. and Soliman, S.M., 2012. Effect of feeding a combination of zinc, manganese and copper methionine chelates of early lactation high producing dairy cow. Food and Nutrition Sciences 3(08): 1084.

Harrison, G.A., Zimmerman, M. and Soriano, F. 2006. Effect of reducing the level of dietary inorganic trace mineral fortification on fecal mineral output and performance in commercial dairy herds In: Proceedings of Alltech's $22^{\text {nd }}$ Annual Symposium, $24^{\text {th }}-26^{\text {th }}$ of April 2006, Lexington, KY, USA.

Hawkes, W.C. and Craig, K.A., 1990. Automated continuousflow colorimetric determination of glutathione peroxidase with dichloroindophenol. Analytical biochemistry 186(1): 46-52.

Horchanok, A., Bomko, V., Kuzmenko, O., Novitskiy, R., Sobolev, O., Tkachenko, M. and Prisjazhnjuk, N., 2019. Influence of chelations on dairy productivity of cows in different periods of manufacturing cycle. Ukrainian Journal of Ecology 9(1): 231-234.

INRA, 2007. Alimentation des bovins, ovins et caprins. Besoins des animaux - valeurs des aliments. Quae éditions, Versailles, France.

Kinal, S., Korniewicz, A., Jamroz, D., Zieminski, R. and Slupczynska, M., 2005. Dietary effects of zinc, copper and manganese chelates and sulphates on dairy cows. Journal of Food Agriculture and Environment 3(1): 168-172.

Kropp, J..R., 1990. Reproductive performance of first-calf heifers supplemented with amino acid chelate minerals. Oklahoma Animal Science Research Report 41 Oklahoma State University, Stillwater, OK, USA, pp. 35-43.

Leeson, S., 2003. A new look at the trace mineral nutrition of poultry: can we reduced environmental burden of poultry manure? In: Lyons, T.P. and Jacques, K.A. (eds.) Nutritional biotechnology in the feed and food industries. Proceedings of Alltech's $19^{\text {th }}$ Annual Symposium, Nottingham University Press, Nottingham, UK, pp. 125-129.

Lin, L., Xiu-dong, L. and Xu-gang, L., 2017. Nutritional strategies for reducing nitrogen, phosphorus and trace mineral excretions of livestock and poultry Journal of Integrative Agriculture 16(12): 2815-2833.

Nocek, J.E., Socha, M.T. and Tomlinson, D.J., 2006. The effect of trace mineral fortification level and source on performance of dairy cattle. Journal of Dairy Science 89(7): 2679-2693.
Nollet, L., Van der Klis, J.D., Lensing, M. and Spring, P., 2007. The effect of replacing inorganic with organic trace minerals in broiler diets on productive performance and mineral excretion. Journal of Applied Poultry Research 16: 592-597.

Paglia, D.E. and Valentine, W.N., 1967. Studies on the quantitative and qualitative characterization of erythrocyte glutathione peroxidase. Journal of Laboratory Clinical Medicine 70(1): 158-69.

Perić, L., Milošević, N., Žikić, D., Bjedov, S., Cvetković, D., Markov, S., Mohnl, M. and Steiner, T., 2010. Effects of probiotic and phytogenic products on performance, gut morphology and cecal microflora of broiler chickens. Archives Animal Breeding 53(3): 350-359.

Petrovič, V., Nollet, L. and Kováč, G., 2010. Effect of dietary supplementation of trace elements on the growth performance and their distribution in the breast and thigh muscles depending on the age of broiler chickens. Acta Veterinaria Brno 79(2): 203-209.

Pino, F. and Heinrichs, A.J., 2016. Effect of trace minerals and starch on digestibility and rumen fermentation in diets for dairy heifers. Journal of Dairy Science 99(4): 2797-2810.

Qiu, J., Lu, X., Ma, L., Hou, C., He, J., Liu, B., Yu, D., Lin, G. and Xu, J., 2020. Low-dose of organic trace minerals reduced fecal mineral excretion without compromising performance of laying hens. AsianAustralasian Journal of Animal Sciences 33(4): 588-596.

Spears, J.W., 1996. Organic trace minerals in ruminant nutrition. Animal Feed Science and Technology 58(1-2): 151-163.

Spolders, M., Höltershinken, M., Meyer, U., Rehage, J and Flachowsky, G., 2010. Assessment of reference values for copper and zinc in blood serum of first and second lactating dairy cows. Veterinary Medicine International 194656. https://doi.org/10.4061/2010/194656

Uchida, K., Mandebvu, P., Ballard, C.S., Sniffen, C.J. and Carter, M.P., 2001. Effect of feeding a combination of zinc, manganese and copper amino acid complexes, and cobalt glucoheptonate on performance of early lactation high producing dairy cows. Animal Feed Science and Technology 93(3-4): 193-203.

Webb, K.E., Wong, E.A., Pan, Y-X., Chen, H., Poole, C.A., Van, L. and Klang, J.E., 2005. The role of peptides in absorption pathways. In: Pickard, J.A. and Tucker, L.A. (eds.) Redefining mineral nutrition. Nottingham University Press, Nottingham, UK, pp. 197-225.

Zhao, J., Shirley, R.B., Vazquez-Anon, M., Dibner, J.J., Richards, J.D., Fisher, P., Hampton, T., Christensen, K.D., Allard, J.P. and Giesen, A.F., 2010. Effects of chelated trace minerals on growth performance, breast meat yield, and footpad health in commercial meat broilers. Journal of Applied Poultry Research 19(4): 365-372. 